\author{
VLADIMÍR ŠIMANSKÝ $^{1}$, MARTIN JURIGA ${ }^{1}$, ŁUKASZ MENDYK ${ }^{2}$ \\ ${ }^{1}$ Slovak University of Agriculture, Faculty of Agrobiology and Food Resources, Department of Soil Science \\ Tr. A. Hlinku 2, 94976 Nitra, Slovakia \\ 2 Poznań University of Life Sciences, Faculty of Agronomy and Bionengineerig, Department of Soil Science and Land Protection \\ Szydlowska St. 50, 60-656 Poznań, Poland
}

\title{
Slope position and management practices as factors influencing selected properties of topsoil
}

\begin{abstract}
An interaction between the slope position and type of soil management practices could be one of the most important factor affecting several soil properties including soil structure. Therefore, we evaluated selected soil properties including soil structure parameters in relation to slope gradient and soil management practices between Trakovice and Bučany villages (western Slovakia). The sampling sites were located in two adjacent, gently sloping fields with a NW-SE orientation. The sites also differ in soil management type: Field No. 1 was used as arable land with intensive cultivation (IC) of crops, while a greening system (GS) had been established on Field No. 2. Soil samples were taken from five geomorphological zones at each slope: summit, shoulder, backslope, toe slope and flat terrain under the slope. Results showed that soil $\mathrm{pH}$, content of soil organic matter (SOM) and carbonates depended on land use of the slopes. In GS, the water-stable macro-aggregates (WSA ${ }_{\mathrm{ma}}$ ) 0.5-3 mm (favourable size fraction) displayed statistical significant quadratic polynomial trend along the slope gradient. In IC the values of mean weight diameter of dry sieved aggregates (MWDd) decreased significantly along the slope gradient, while in GS the opposite trend was observed. In IC significant correlations between carbonates content $(\mathrm{r}=-0.775, \mathrm{P}<0.01)$, humic acids $(\mathrm{HA})$ content $(\mathrm{r}=0.654, \mathrm{P}<0.05)$, colour quotients of humic substances $(\mathrm{r}=-0.706, \mathrm{P}<0.05)$, colour quotients of HA $(\mathrm{r}=-0.723, \mathrm{P}<0.05)$ and MWDd were determined. In GS higher content of carbonates was followed by a decrease in content WSA $_{\mathrm{ma}}$, MWDd, mean weight diameter of wet sieved aggregates (MWDw) and stability index of aggregates. At the same time stabile and labile soil organic matter improved soil structure parameters in GS.
\end{abstract}

Keywords: soil structure, soil organic matter, intensive cultivation, greening system, slope

\section{INTRODUCTION}

Soil structure can be defined as the arrangement of different constituents of soil (e.g. Laatsh 1954, Fiedler and Reissing 1964; Mückenhausen 1975, Rząsa and Owczarzak 2004). A soil with good structure has low compaction or bulk density and a large amount of pore space. These soils have high infiltration, quick water movement through the profile, high water retention, high water availability to roots, low crusting on soil surface, high gas exchange, high nutrient availability, easier root penetration, reduced surface runoff and soil erosion (Kay 1998, Shukla 2014). Stability of soil structure is one of the most important indicators of soil quality. Numerous studies suggest that organic matter (OM), sesquioxides, clay minerals, microbial activity and soil management practices play an important role in the formation of aggregates as the basic unit of soil structure (Tisdall and Oades 1982; Bronick and Lal 2005; Gajewski et al. 2016, Polláková et al. 2018, Kobierski et al. 2018). In addition, the stability of aggregates determines soil resistance to erosion (Barthés and Roose 2002).
In Slovakia, the most important degradation processes include water and wind erosion, which have a direct impact on soil structure (Šimanský et al. 2018). Water erosion presents a potential threat to $46 \%$ of agricultural land $\left(10878.39 \mathrm{~km}^{2}\right)$ and wind erosion processes potentially threaten $9 \%$ of agricultural land, which amounts to $2024.29 \mathrm{~km}^{2}$ (Šimanský et al. 2018). Small particles as well as the micro- and smaller macro-aggregates are being subjected to erosion (Barthés and Roose 2002; Efthimiou 2018), especially on soils that have an adverse soil structure due to their intensive cultivation (Steinhoff-Knopp and Burkhard 2018). Soil erosion have also significant effect on changes in soil properties what results in increased field heterogeneity. For example, the increase in soil organic carbon content (SOC) increases aggregation as well as the water stability of aggregates. Different SOC fractions also influence different macro-aggregate-associated properties. Topographic features such as slope can also influence the SOC distribution in macro-aggregates, since considerable amounts of light SOC fractions can be redistributed and concentrated near the soil surface on 
the toe slope due to water erosion and transport from shoulder or backslope positions (Gregorich et al. 1998). The redistribution of SOC can, in turn, affect the formation, stability and hydrological properties of aggregates (Shukla 2014). Slope gradient and change in land use are known to influence soil quality, and the assessment of soil quality is important in determining sustainable land-use and soil-management practices (Cambardella and Elliot 1992; Tisdall 1996, Chun-Chih et al. 2004, Nabiollahi et al. 2018).

Thus, we hypothesised that creating a greening system on a slope is a factor that improves stability of soil structure in comparison to an intensively cultivated slope. Moreover, a more stable soil structure should be present on the toe slope (or within the accumulation zone of the slope). Therefore, we evaluated soil structure parameters as one of the most important soil quality parameters in relation to slope gradient and soil management practices.

\section{MATERIALS AND METHODS}

The study sites were located in the north-western part of the Danube lowland (Fig. 1) between Trakovice and Bučany villages (Trnava Region, western Slovakia). The geological substrate of the studied area is loess of several metres thick. The average monthly temperature is $10^{\circ} \mathrm{C}\left(9-10^{\circ} \mathrm{C}\right)$, while precipitation is $525 \mathrm{~mm}$ (450-600 mm, Tarábek 1980).

The soil cover of the study area comprises of a Regosols and Chernozems complex (Societas Pedologica Slovaca 2014). Regosols occurred along both of the studied slopes while buried Chernozems were present at the flat terrain under the slopes. The sampling sites were in two adjacent fields. Both were gently sloping $\left(8^{\circ}\right)$ with a NW-SE orientation. According to the slope forms and surface pathways, Field 1 was located on a concave slope, and Field 2 on a convex-concave slope. The fields also differed in soil management type. Field 1 was used as arable land with intensive cultivation (IC) of crops by standard conventional tillage system. Conventional tillage consisted of mouldboard ploughing to the $0.22-0.25 \mathrm{~m}$ depth in autumn, followed by disking/ rolling/levelling and planting in dependence to cultivated crops. In the sampling year (2018) the field was planted with maize and the tillage rows were oriented along the slope direction, with spacing of $70 \mathrm{~cm}$. On Field 2, a greening system (GS) had been established in 2012. Plant cover has been cut being and mulched there twice a year.

In 2018, both studied slopes (sampling fields) were divided into five zones: summit (S), shoulder $(\mathrm{SH})$,

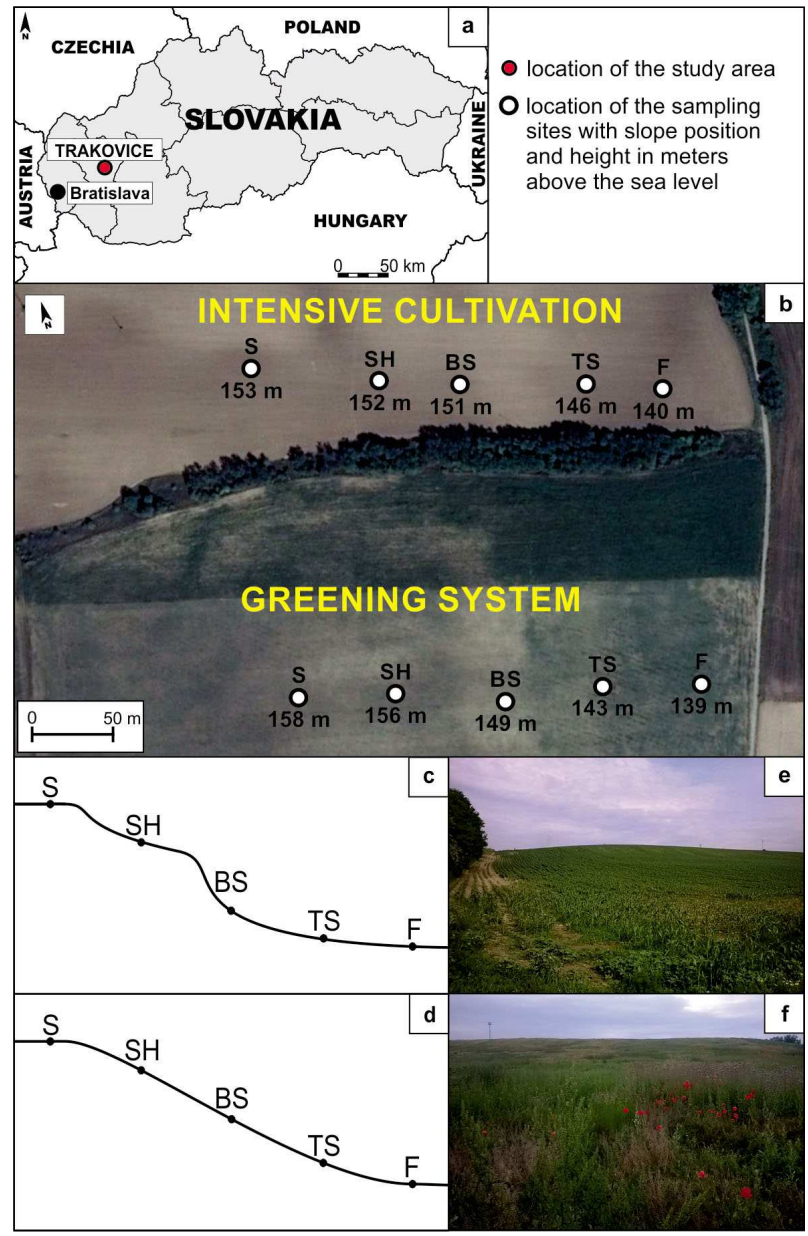

FIGURE 1. Location of the study area within the borders of Slovakia and sampling plots within the analysed slopes

backslope (BS), toe slope (TS) and flat terrain under the slope (F). A total of 10 soils pits were prepared (one per slope zone for both analysed slopes). Soil samples were collected from the cultivated soil layer (upper $20 \mathrm{~cm}$ ). The following soil properties were determined in the collected samples: $\mathrm{pH}$ of the soilto-solution ratio of $1: 2.5$ using $\mathrm{H}_{2} \mathrm{O}$ as the suspension medium; content of soil organic carbon (SOC) by sample oxidation in the mixture of $\mathrm{K}_{2} \mathrm{Cr}_{2} \mathrm{O}_{7}$ and $\mathrm{H}_{2} \mathrm{SO}_{4}$ (Dziadowiec and Gonet 1999); and content of carbonates by the volumetric method using a Jankov calcimeter. Particle-size distribution was determined by pipette method (Hrivňaková et al. 2011), texture classes were described according to USDA (Soil Survey Division Staff 1993). The labile carbon content $\left(\mathrm{C}_{\mathrm{L}}\right)$ was determined using $0.005 \mathrm{~mol} \mathrm{dm}^{-3}$ $\mathrm{KMnO}_{4}($ Loginow et al. 1987) and hot water extracted carbon $\left(\mathrm{C}_{\mathrm{HWE}}\right)$ was determined according to the method of Körschner et al. (1990). The group and fraction composition of humic substances (HS) was determined by the Belchikova and Kononova method 
(Dziadowiec and Gonet 1999). The light absorbance of humic substances (HS) and humic acids (HA) was measured at 465 and $650 \mathrm{~nm}$ using a Jenway 6400 Spectrophotometer to calculate the colour quotients

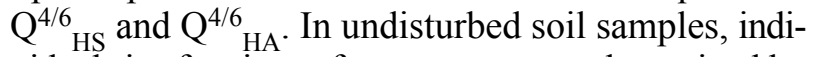
vidual size fractions of aggregates were determined by dry sieving of soil through sieves with mesh diameters $>7,7-5,5-3,3-1,1-0.5,0.5-0.25 \mathrm{~mm}$ as dry sieved macro-aggregates (DSA ${ }_{\text {ma }}$ ) and $<0.25 \mathrm{~mm}$ as dry sieved micro-aggregates ( $\left.\mathrm{DSA}_{\mathrm{mi}}\right)$. These fractions of air-dried aggregates were used to determine water-stable macro- (WSA ${ }_{\text {ma }}$ ) and microaggregates (WSA ${ }_{\text {mi }}$ ) by the Baksheev method (Vadjunina and Korchagina, 1986). Also, the mean weight diameters (MWD: for both dry sieved aggregates, MWDd; and for water-stable aggregates, MWDw), vulnerability coefficient $(\mathrm{Kv})$ by the method of Valla et al. (2000), and the stability index of water-stable aggregates ( $\mathrm{Sw}$ ) by the Henin method (Zaujec and Šimanský, 2006) were calculated.

One-way analysis of variance (ANOVA) and the least significant difference (LSD) method was used to compare treatment means for the two types of managements (IC and GS) at $\mathrm{P}<0.05$. The interrelations between $\mathrm{SOM}$ and soil structure parameters were determined through a correlation matrix. For the expression of soil structure parameter dynamics along the slope gradient, linear and quadratic polynomial regression models were used. All the statistical analyses were performed using Statgraphics Centurion XV.I software (Statpoint Technologies, Inc., USA).

\section{RESULTS AND DISCUSSION}

Basic soil properties are presented in Table 1. In both types of management, the soils were weakly alkaline, and the $\mathrm{pH}$ ranged from 7.70-7.94. Similarly, rather low and medium SOC content (from 11.5 to $14.4 \mathrm{~g} \mathrm{~kg}^{-1}$ on the IC and from 7.90 to $15.9 \mathrm{~g} \mathrm{~kg}^{-1}$ on the GS) and high and relatively high content of hot water extracted carbon (from 0.492 to $0.702 \mathrm{~g} \mathrm{~kg}^{-1}$ on the IC and from 0.378 to $0.767 \mathrm{~g} \mathrm{~kg}^{-1}$ on the GS) were determined for both parts of the analysed slope. The content of labile carbon ranged from 1.09 to $1.45 \mathrm{~g} \mathrm{~kg}^{-1}$ (8.9 to $10.1 \%$ of SOC) and from 0.674 to $1.54 \mathrm{~g} \mathrm{~kg}^{-1}$ ( 8.13 to $9.72 \%$ of SOC) in the intensively cultivated slope and in the greening system, respectively. Contents of carbonates depended on - land use and slope form (Table 1). The highest content of carbonates was determined for the soil sample in the summit in IC $\left(180 \mathrm{~g} \mathrm{~kg}^{-1}\right)$ and the lowest for the flat part of the GS $\left(50 \mathrm{~g} \mathrm{~kg}^{-1}\right)$. Soil texture was silt loam, with the clay content ranging from 14 to $22 \%$. In IC and GS, the content of carbon in extracted humic substances (CHS, Table 2.) ranged from 4.17 to 5.2 and from 2.82 to $6.37 \mathrm{~g} \mathrm{~kg}^{-1}$ which comprises 34 $37 \%$ and $35-40 \%$ of SOC, respectively. The average

TABLE 1. Basic soil properties with results of ANOVA and LSD analyses results showing the difference between studied slopes

\begin{tabular}{|c|c|c|c|c|c|c|c|c|c|}
\hline \multirow[t]{2}{*}{ Land use } & \multirow{2}{*}{$\begin{array}{l}\text { Slope } \\
\text { position }\end{array}$} & \multirow{2}{*}{$\mathrm{pH} \mathrm{H}_{2} \mathrm{O}$} & \multirow{2}{*}{$\frac{\mathrm{SOC}}{\left[\mathrm{g} \mathrm{kg}^{-1}\right]}$} & \multirow[t]{2}{*}{$\mathrm{C}_{\mathrm{L}}$} & \multirow[t]{2}{*}{$\mathrm{C}_{\mathrm{HWE}}$} & \multirow[t]{2}{*}{$\mathrm{CaCO}_{3}$} & \multicolumn{3}{|c|}{ Percentage share of fraction $[\mathrm{mm}]$} \\
\hline & & & & & & & $2-0.05$ & $0.05-0.002$ & $<0.002$ \\
\hline \multirow[t]{5}{*}{$\mathrm{IC}$} & $\mathrm{S}$ & 7.73 & 12.2 & 1.086 & 0.681 & 180 & 32 & 54 & 15 \\
\hline & $\mathrm{SH}$ & 7.81 & 11.5 & 1.160 & 0.581 & 170 & 23 & 63 & 14 \\
\hline & $\mathrm{BS}$ & 7.75 & 14.3 & 1.447 & 0.635 & 120 & 26 & 57 & 17 \\
\hline & $\mathrm{TS}$ & 7.73 & 14.4 & 1.354 & 0.702 & 100 & 26 & 58 & 16 \\
\hline & $\mathrm{F}$ & 7.70 & 14.1 & 1.140 & 0.492 & 100 & 23 & 58 & 19 \\
\hline \multirow[t]{5}{*}{ GS } & $\underline{\mathrm{S}}$ & 7.86 & 13.7 & 1.228 & 0.537 & 60 & 23 & 57 & 20 \\
\hline & $\mathrm{SH}$ & 7.94 & 7.90 & 0.674 & 0.378 & 120 & 19 & 61 & 20 \\
\hline & $\mathrm{BS}$ & 7.86 & 11.7 & 0.955 & 0.475 & 80 & 25 & 55 & 20 \\
\hline & $\mathrm{TS}$ & 7.78 & 15.5 & 1.320 & 0.588 & 40 & 28 & 55 & 17 \\
\hline & $\mathrm{F}$ & 7.85 & 15.9 & 1.543 & 0.767 & 50 & 30 & 51 & 19 \\
\hline \multicolumn{10}{|c|}{ ANOVA and LSD analyses results } \\
\hline IC & & $7.74 \pm 0.04^{\mathrm{a}}$ & $13.3 \pm 1.30^{\mathrm{a}}$ & $1.237 \pm 0.15^{\mathrm{a}}$ & $0.608 \pm 0.08^{\mathrm{a}}$ & $133 \pm 35.2^{\mathrm{b}}$ & $25.9 \pm 3.28^{\mathrm{a}}$ & $58.0 \pm 3.03^{\mathrm{a}}$ & $16.1 \pm 1.79^{\mathrm{a}}$ \\
\hline GS & & $7.86 \pm 0.05^{b}$ & $13.0 \pm 3.10^{\mathrm{a}}$ & $1.144 \pm 0.32^{\mathrm{a}}$ & $0.549 \pm 0.14^{\mathrm{a}}$ & $72 \pm 29.7^{\mathrm{a}}$ & $25.1 \pm 4.09^{\mathrm{a}}$ & $55.9 \pm 3.22^{\mathrm{a}}$ & $19.0 \pm 1.36^{\mathrm{b}}$ \\
\hline p-value & & 0.0000 & 0.7381 & 0.4098 & 0.2560 & 0.0232 & 0.6353 & 0.1396 & 0.0006 \\
\hline
\end{tabular}

Land use: IC - intensive cultivation, GS - reening system; Slope position: $\mathrm{S}$ - summit, $\mathrm{SH}$ - shoulder, BS - back slope, $\mathrm{S}$ - toe slope, $\mathrm{F}$ - flat; $\mathrm{SOC}-$ soil organic carbon, $\mathrm{C}_{\mathrm{L}}-$ labile carbon, $\mathrm{C}_{\mathrm{HWE}}-$ hot water extracted carbon, $\mathrm{CaCO}_{3}-\mathrm{content}$ of carbonates; Different letters ( $a, b)$ indicate significant differences between studied slopes at $\mathrm{P}<0.05$ according to LSD test 
TABLE 2. Soil organic matter properties with results of ANOVA and LSD analyses results showing the difference between studied slopes

\begin{tabular}{|c|c|c|c|c|c|c|c|c|c|c|}
\hline \multirow{2}{*}{$\begin{array}{l}\text { Land } \\
\text { use }\end{array}$} & \multirow{2}{*}{$\begin{array}{l}\text { Slope } \\
\text { position }\end{array}$} & CHS & $\mathrm{CHA}$ & CFA & CHS & CHA & CFA & \multirow[t]{2}{*}{ CHA:CFA } & \multicolumn{2}{|l|}{$\mathrm{Q}^{4 / 6}$} \\
\hline & & \multicolumn{3}{|l|}{$\left[\mathrm{g} \mathrm{kg}^{-1}\right]$} & \multicolumn{3}{|c|}{ as $\%$ of the SOC } & & $\overline{\mathrm{HS}}$ & HA \\
\hline \multirow[t]{5}{*}{$\mathrm{IC}$} & $\mathrm{S}$ & 4.61 & 2.45 & 2.16 & 37.76 & 20.07 & 17.69 & 1.13 & 5.54 & 4.12 \\
\hline & $\mathrm{SH}$ & 4.17 & 2.45 & 1.72 & 36.29 & 21.32 & 14.97 & 1.42 & 6.47 & 4.44 \\
\hline & $\mathrm{BS}$ & 5.20 & 2.75 & 2.45 & 36.39 & 19,24 & 17.14 & 1.12 & 4.81 & 3.85 \\
\hline & $\mathrm{TS}$ & 5.16 & 2.86 & 2.30 & 35.86 & 19,87 & 15.98 & 1.24 & 4.31 & 3.61 \\
\hline & $\mathrm{F}$ & 4.82 & 2.72 & 2.10 & 34.28 & 19,35 & 14.94 & 1.30 & 4.70 & 3.82 \\
\hline \multirow[t]{5}{*}{ GS } & $\mathrm{S}$ & 5.20 & 2.89 & 2.31 & 38.10 & 21.17 & 16.93 & 1.25 & 4.56 & 3.77 \\
\hline & $\mathrm{SH}$ & 2.82 & 1.44 & 1.38 & 35.70 & 18.23 & 17.47 & 1.04 & 5.55 & 3.87 \\
\hline & $\mathrm{BS}$ & 4.58 & 2.72 & 1.86 & 39.01 & 23.17 & 15.84 & 1.46 & 4.58 & 3.76 \\
\hline & $\mathrm{TS}$ & 5.99 & 3.68 & 2.31 & 38.67 & 23.76 & 14.91 & 1.59 & 3.71 & 3.38 \\
\hline & $\mathrm{F}$ & 6.37 & 3.75 & 2.62 & 40.14 & 23.63 & 16.51 & 1.43 & 3.90 & 3.45 \\
\hline \multicolumn{11}{|c|}{ ANOVA and LSD analyses results } \\
\hline \multicolumn{2}{|l|}{ IC } & $4.79 \pm 0.40^{\mathrm{a}}$ & $2.64 \pm 0.20^{\mathrm{a}}$ & $2.15 \pm 0.20^{\mathrm{a}}$ & $36.1 \pm 0.52^{\mathrm{a}}$ & $19.9 \pm 0.78^{\mathrm{a}}$ & $16.2 \pm 0.48^{\mathrm{a}}$ & $1.24 \pm 0.14^{\mathrm{a}}$ & $5.17 \pm 0.81^{\mathrm{a}}$ & $3.97 \pm 0.0^{\mathrm{a}}$ \\
\hline \multicolumn{2}{|l|}{ GS } & $4.99 \pm 1.30^{\mathrm{a}}$ & $2.90 \pm 0.90^{\mathrm{a}}$ & $2.09 \pm 0.50^{\mathrm{a}}$ & $38.3 \pm 1.28^{\mathrm{b}}$ & $22.0 \pm 2.21^{\mathrm{b}}$ & $16.3 \pm 0.28^{\mathrm{a}}$ & $1.36 \pm 0.23^{\mathrm{a}}$ & $4.46 \pm 0.68^{\mathrm{a}}$ & $3.64 \pm 0.20^{\mathrm{a}}$ \\
\hline \multicolumn{2}{|c|}{ P-value } & 0.6554 & 0,3876 & 0.7573 & 0.0075 & 0.0184 & 0.8008 & 0.1645 & 0.1946 & 0.0960 \\
\hline
\end{tabular}

Land use: IC - intensive cultivation, GS - greening system

Slope position: $\mathrm{S}$ - summit, $\mathrm{SH}$ - shoulder, BS - back slope, TS - toe slope, F - flat

CHS - humic substances carbon, CHA - humic acids carbon, CFA - fulvic acids carbon, $\mathrm{Q}^{4 / 6}-$ color quotient 465 to 650 nm HS - humic substances, HA - humic acids

Different letters $(\mathrm{a}, \mathrm{b})$ between lines indicate that treatment means are significantly different at $\mathrm{P}<0.05$ according to LSD test

content of extracted humic acid carbon (CHA) was lower in IC $\left(2.65 \mathrm{~g} \mathrm{~kg}^{-1}\right)$ than in GS $\left(2.90 \mathrm{~g} \mathrm{~kg}^{-1}\right)$. The opposite was observed for the fulvic acids (FA), as the average content of extracted fulvic acids carbon (CFA) was slightly higher in IC $\left(2.15 \mathrm{~g} \mathrm{~kg}^{-1}\right)$ than in GS (2.09 $\left.\mathrm{g} \mathrm{kg}^{-1}\right)$. We evaluated the humus quality with regard to the soil managements on carbon of HA and FA ratio (CHA:CFA) as well as with regard to the optical parameters of humic substances $\left(\mathrm{Q}^{4 / 6}{ }_{\mathrm{HS}}\right)$ and $\mathrm{HA}\left(\mathrm{Q}^{4 / 6}{ }_{\mathrm{HA}}\right)$. In GS, the average values of the CHA:CFA ratio were wider than in IC. The average values of $\mathrm{Q}^{4 / 6} \mathrm{HS}$ and $\mathrm{Q}^{4 / 6}{ }_{\mathrm{HA}}$ and the degree of humification - DH (expressed as CHA from SOC) were also more favourable in GS than in IC (Table 2).

Intensive soil management practices, which are very often incorrect, accelerate soil erosion, which was reflected in the differences between the soil profiles on the two slopes. Loss of soil material from the surface horizon at the summit position and its delivery to the accumulation zone (toe slope and flat terrain under the slope) was clearly visibly due to the human induced erosion. This phenomenon affected and changed the original soil cover on the analysed slopes. Nowadays arable horizon material is mixed with the parent material mainly on the intensively cultivated (IC) slope, while this situation took place on the both analysed slopes (IC and GS) in the past due to its former cultivation. Moreover, eroded material accumulating on the toe slope and under the slope resulted in the burial of the original mollic surface horizon, which is present at the depth of more than $50 \mathrm{~cm}$ (Šimanský et al. 2014). Therefore, the soil properties along the slope gradient were affected. Slope gradient is considered to be one of the most important factors influencing soil quality because of its effects on variations in several soil properties, and thus on crop yield (PazKagan et al. 2016). The loss and degradation of soils have negative impacts on nutrient cycling and carbon stocks mainly in shoulder and backslope positions (Dominati et al. 2010).

The one-way ANOVA analysis showed significant differences between both management types (IC vs GS) for soil $\mathrm{pH}, \mathrm{CaCO}_{3}, \mathrm{CHS}$ as \% of the $\mathrm{SOC}$ (expressed also as degree of humification) and CHA as $\%$ of the SOC (Tables 1 and 2).

Types of managements had statistically significant influence on soil structure parameters (Table 3 ) and their values in greening system (GS) were better in comparison to intensive cultivation (IC).

Content of DSAmi and DSAma ranged from 35 to $54 \%$ and from 16 to $42 \%$ in the IC and GS, respectively. Transfer (transport) of soil aggregates down slope via erosion can increase content of DSA ${ }_{\mathrm{mi}}$ while decrease the $\mathrm{DSA}_{\mathrm{ma}}$ in lower parts of the slopes. This arrangement was much more demonstrable in the IC (Fig. 2A). Nevertheless, content of $\mathrm{DSA}_{\mathrm{mi}}$ and $\mathrm{DSA}_{\mathrm{ma}}$ did not significantly correlate with slope forms, as the 


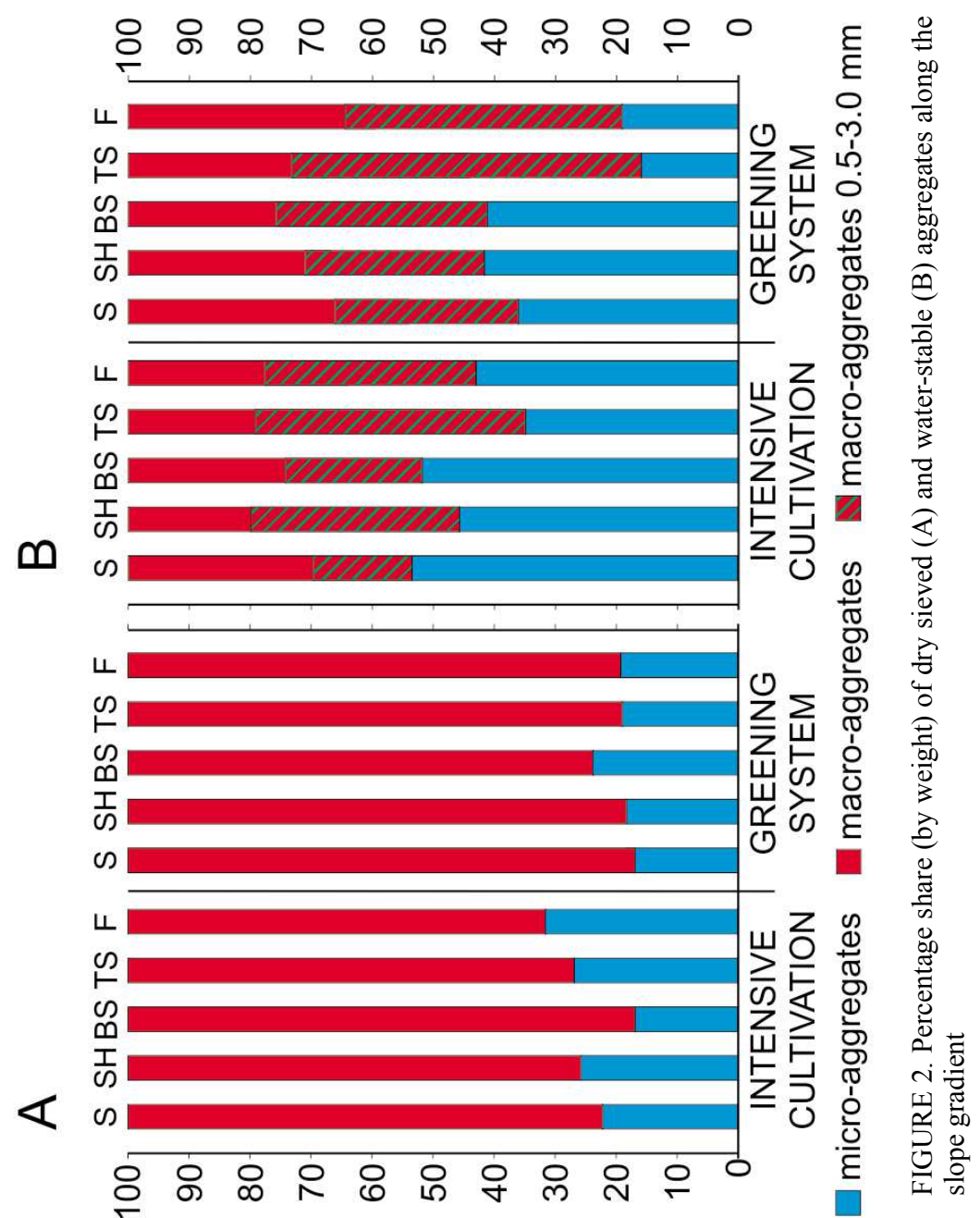

dynamics of $\mathrm{DSA}_{\mathrm{mi}}$ and $\mathrm{DSA}_{\mathrm{ma}}$ content revealed no trend in either slope's gradient. Despite this fact, the quadratic polynomial trend expressed changes in contents of DSA $\mathrm{mi}_{\mathrm{mi}}$ and DSA $\mathrm{ma}_{\mathrm{m}}$ along the slope in the best way (Table 4). Soil structure can be modified by soil management practices (Bronick and Lal 2005), while significant deterioration of soil structure and increase in soil erosion is observed in intensive land use activity (Steinhoff-Knopp and Burkhard 2018), which our findings confirmed. Content of $\mathrm{WSA}_{\mathrm{mi}}$ and $\mathrm{WSA}_{\mathrm{ma}}$ are very important indicators of soil structure (stability, vulnerability or water resistance; Šimanský et al. 2018). Similarly the dry sieved aggregates, content of $\mathrm{WSA}_{\mathrm{mi}}$ decreased and content of WSA $\mathrm{ma}_{\mathrm{inc}}$ ineased from the upper to the lower parts of the slope (Fig. 2B). Since the contribution of macro-aggregates of size $0.5-3$ $\mathrm{mm}$ is important from the agronomical point of view (Demo et al. 1995) we evaluated the content of these aggregates additionally. The content of favourable size fraction of $\mathrm{WSA}_{\mathrm{ma}} 0.5-3 \mathrm{~mm}$ increased along the slope, while the highest content of these aggregates was observed in flat terrain under the slope for both management types (Fig. 2B). Although only in the GS did the WSA $_{\mathrm{ma}} 0.5-3 \mathrm{~mm}$ show a statistically significant quadratic polynomial trend along the slope gradient. There is a linear increase in WSA $_{\mathrm{ma}} 0.5-3 \mathrm{~mm}$ content by $8 \%$ every $80-120 \mathrm{~m}$ along the slope (upper to lower slope). In the IC, the values of MWDd decreased significantly in the same direction (Fig. 3A), which was clearly explained with the quadratic polynomial model (Table 3). Based on the linear 
model, the MWDd decreased by $0.15 \mathrm{~mm}$ during every $80-120 \mathrm{~m}$ along the slope gradient. On the other hand, the values of MWDd increased significantly in GS along the slope (Fig. 3A) and the quadratic polynomial trend was significant (Table 3 ). The MWDw values were significantly lower on the backslope as compared to the summit and the accumulation zone of the slope (TS and F parts) indicating more intense erosion (Fig. 3A). Probably it was the reason why no statistically proven decreasing or increasing trends of MWDw were observed both along the IC and GS parts of the slope. In the case of soil structure vulnerability $(\mathrm{Kv})$ and MWDw, similar effects were observed (Fig. 3B). In GS, the aggregate stability $(\mathrm{Sw})$ increased down the slope without any statistical significance. On the IC it was not possible to determine any trend along the slope (Fig. 3C). The arrangement of the soil structure parameter values, as well as the statistical results discussed above, is fully in line with our assumptions. Soil erosion is the well-known result of incorrect soil management practices (Zhang et al. 2008, Liang et al. 2010). This is especially true in the case of inappropriate crop cultivation, as on the intensively cultivated part of the analysed slope. As mentioned before, maize was cultivated with an inter-line spacing of $70 \mathrm{~cm}$ and the direction of the lines was oriented along the slope, which obviously accelerated soil erosion. Since this process was more explicit on the intensively cultivated slope, the soil structure was unable to stabilise, in contrast to the greening system.

Under both type of soil management types, carbonates content was relatively high, but on average in the IC, their content was almost double $\left(133 \mathrm{~g} \mathrm{~kg}^{-1}\right)$ than in the GS $\left(72 \mathrm{~g} \mathrm{~kg}^{-1}\right)$. Apart from the negative correlation between carbonates content and MWDd, no significant relations were determined in the IC (Table 5). Intensive cultivation can be the main reason for the negative effect of carbonates in decreasing MWDd and can have an insufficient effect on other parameters of soil structure, because IC favours the surface runoff and impedes the formation of secondary carbonates.

TABLE 4. Trends of soil structure parameters along the slope gradient

\begin{tabular}{|c|c|c|c|c|c|}
\hline Land use & $\begin{array}{l}\text { Soil structure } \\
\text { parameter }\end{array}$ & Linear model & $\mathrm{R}^{2}$ & Quadratic polynomial model & $\mathrm{R}^{2}$ \\
\hline \multirow[t]{9}{*}{$\mathrm{IC}$} & $\mathrm{DSA}_{\mathrm{mi}}$ & $\mathrm{y}=2.00 \mathrm{x}+18.66$ & 0.3293 & $\mathrm{y}=1.52 \mathrm{x} 2-7.09 \mathrm{x}+29.27$ & 0.5935 \\
\hline & $\mathrm{DSA}_{\mathrm{ma}}$ & $y=-2.00 x+81.34$ & 0.3293 & $y=-1.52 x 2+7.09 x+70.73$ & 0.5935 \\
\hline & $\mathrm{WSA}_{\mathrm{mi}}$ & $y=-3.21 x+55.37$ & 0.4576 & $y=0.65 x 2-7.13 x+59.94$ & 0.4841 \\
\hline & $\mathrm{WSA}_{\mathrm{ma}}$ & $y=3.21 x+44.64$ & 0.4579 & $y=-0.65 x 2+7.13 x+40.07$ & 0.4843 \\
\hline & $\mathrm{WSA}_{\mathrm{ma}} 0.5-3$ & $y=4.67 x+16.34$ & 0.4458 & $y=-1.56 x 2+14.03 x+5.42$ & 0.5156 \\
\hline & MWDd & $y=-0.15 x+2.81$ & 0.9277 & $y=-0.01 x 2-0.12 x+2.78$ & 0.9291 \\
\hline & MWDw & $y=0.01 x+0.36$ & 0.0177 & $y=0.02 x 2-0.12 x+0.51$ & 0.3341 \\
\hline & $\mathrm{Kv}$ & $y=-0.49 x+8.18$ & 0.1328 & $y=-0.56 \times 2+2.87 x+4.25$ & 0.3754 \\
\hline & $\mathrm{Sw}$ & $y=0.03 x+0.60$ & 0.3183 & $y=-0.01 x 2+0.06 x+0.57$ & 0.3254 \\
\hline \multirow[t]{9}{*}{ GS } & $\mathrm{DSA}_{\mathrm{mi}}$ & $y=0.52 x+17.87$ & 0.0987 & $y=-0.91 x 2+5.95 x+11.53$ & 0.5209 \\
\hline & $\mathrm{DSA}_{\mathrm{ma}}$ & $y=-0.52 x+82.13$ & 0.0987 & $y=0.91 x 2-5.95 x+88.47$ & 0.5209 \\
\hline & $\mathrm{WSA}_{\mathrm{mi}}$ & $y=-5.98 x+48.64$ & 0.5812 & $y=-2.12 x 2+6.72 x+33.82$ & 0.6833 \\
\hline & $\mathrm{WSA}_{\mathrm{ma}}$ & $y=5.97 x+51.37$ & 0.5809 & $y=2.12 x 2-6.73 x+66.19$ & 0.6831 \\
\hline & $\mathrm{WSA}_{\mathrm{ma}} 0.5-3$ & $y=7.89 x+17.65$ & 0.8064 & $y=1.07 x 2+1.45 x+25.17$ & 0.8273 \\
\hline & MWDd & $y=0.07 x+1.71$ & 0.1938 & $y=0.12 x 2-0.64 x+2.54$ & 0.9414 \\
\hline & MWDw & $y=0.05 x+0.70$ & 0.0852 & $y=0.07 x 2-0.38 x+1.20$ & 0.3726 \\
\hline & $\mathrm{Kv}$ & $y=-0.04 x+2.59$ & 0.0190 & $y=-0.12 x 2+0.69 x+1.73$ & 0.2264 \\
\hline & $\mathrm{Sw}$ & $y=0.10 x+0.59$ & 0.6388 & $y=0.03 x 2-0.10 x+0.83$ & 0.7360 \\
\hline
\end{tabular}

Land use: IC - intensive cultivation, GS - greening system; Slope position: S - summit, SH - shoulder, BS - back slope, TS - toe slope, F - flat; Soil structure parameters: DSAmi - dry sieved micro-aggregates, DSA $\mathrm{ma}_{-}$- dry sieved macro-aggregates, $\mathrm{WSA}_{\mathrm{mi}}$ - water-stable micro-aggregates, $\mathrm{WSA}_{\mathrm{ma}}$ - water-stable macro-aggregates, WSA $_{\text {ma }}$ 0.5-3 - water-stable macro-aggregates from 0.5 to $3.0 \mathrm{~mm}$, MWDd - mean weight diameters for dry sieved aggregtes, MWDw - mean weight diameters for water-stable aggregates, $\mathrm{Kv}$ - vulnerability coefficient, Sw - stability index of water-stable aggregates 

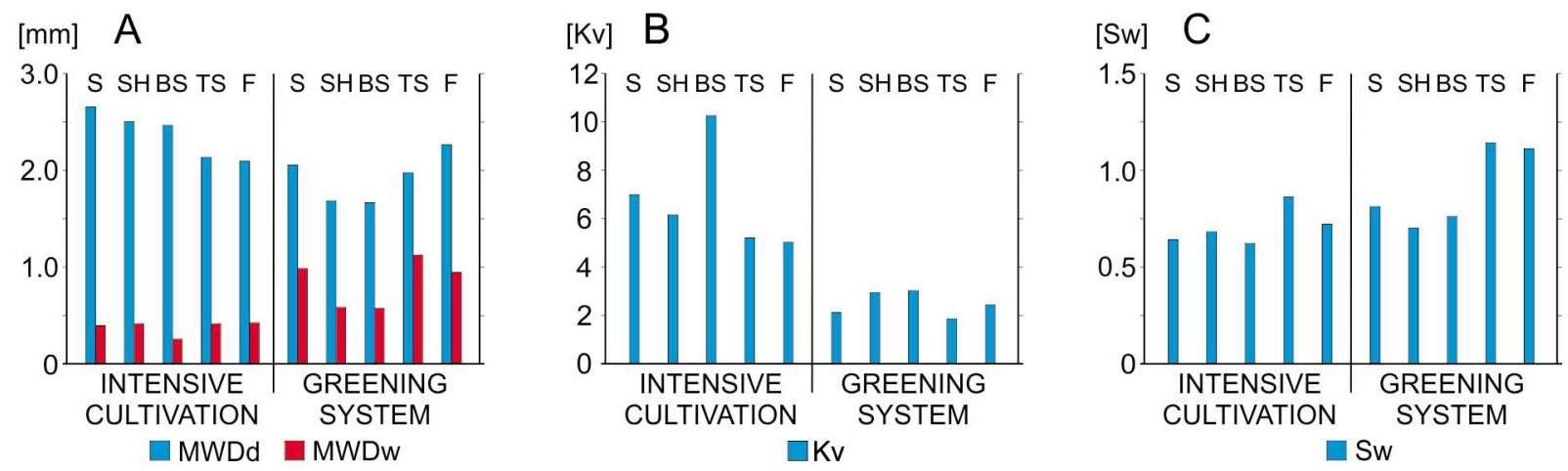

FIGURE 3. Values of mean weight diameter of dry sieved (MDWd) and water-stable aggregates (MDWw; A), vulnerability coefficients $(\mathrm{Kv} ; \mathrm{B})$ and of stability index of water-stable aggregates $(\mathrm{Sw} ; \mathrm{C})$ along the slope gradient

TABLE 5. Correlation coefficients between soil parameters on the analysed slopes

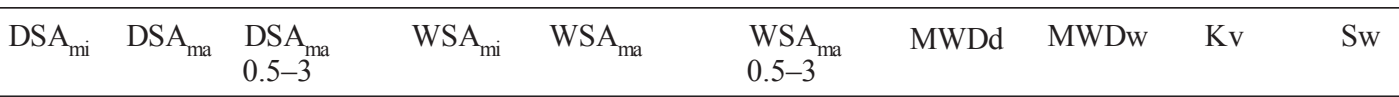

\section{INTENSIVE CULTIVATION}

\begin{tabular}{|c|c|c|c|c|c|c|c|c|c|c|}
\hline $\mathrm{CaCO}_{3}$ & n.s. & n.s. & n.s. & n.s. & n.s. & n.s. & $-0.775 * *$ & n.s. & n.s. & n.s. \\
\hline SOC & n.s. & n.s. & n.s. & n.s. & n.s. & n.s. & n.s. & n.s. & n.s. & n.s. \\
\hline $\mathrm{C}_{\mathrm{L}}$ & n.s. & n.s. & $0.774 * *$ & n.s. & n.s. & n.s. & n.s. & n.s. & n.s. & n.s. \\
\hline $\mathrm{C}_{\mathrm{HWE}}$ & n.s. & n.s. & n.s. & n.s. & n.s. & n.s. & n.s. & n.s. & n.s. & n.s. \\
\hline CHS & n.s. & n.s. & n.s. & n.s. & n.s. & n.s. & n.s. & n.s. & n.s. & n.s. \\
\hline $\mathrm{CHA}$ & n.s. & n.s. & n.s. & n.s. & n.s. & n.s. & $0.654^{*}$ & n.s. & n.s. & n.s. \\
\hline CFA & n.s. & n.s. & n.s. & n.s. & n.s. & n.s. & n.s. & n.s. & n.s. & n.s. \\
\hline $\mathrm{DH}$ & n.s. & n.s. & n.s. & n.s. & n.s. & n.s. & n.s. & n.s. & n.s. & n.s \\
\hline CHA:CFA & n.s. & n.s. & n.s. & n.s. & n.s. & n.s. & n.s. & n.s. & n.s. & n.s. \\
\hline $\begin{array}{l}\mathrm{Q}^{4 / 6} \mathrm{HS} \\
\end{array}$ & n.s. & n.s. & n.s. & n.s. & n.s. & n.s. & $-0.706^{*}$ & n.s. & n.s. & n.s. \\
\hline $\mathrm{Q}_{\mathrm{HA}}^{4 / 6}$ & n.s. & n.s. & n.s. & n.s. & n.s. & n.s. & $-0.723 *$ & n.s. & n.s. & n.s. \\
\hline \multicolumn{11}{|c|}{ GREENING SYSTEM } \\
\hline $\mathrm{CaCO}_{3}$ & n.s. & n.s. & $0.807 * *$ & $0.736^{*}$ & $-0.736^{*}$ & n.s. & $-0.701 *$ & $-0.715^{*}$ & n.s. & $-0.785 * *$ \\
\hline SOC & n.s. & n.s. & $-0.810 * *$ & $-0.802 * *$ & $0.802^{* *}$ & n.s. & $0.826^{* *}$ & $0.752 *$ & n.s. & $0.845^{* *}$ \\
\hline $\mathrm{C}_{\mathrm{L}}$ & n.s. & n.s. & $-0.787 * *$ & $-0.795 * *$ & $0.795^{* *}$ & $0.632 *$ & $0.921 * * *$ & $0.722 *$ & n.s. & $0.834 * *$ \\
\hline $\mathrm{C}_{\mathrm{HWE}}$ & n.s. & n.s. & $-0.758^{*}$ & $-0.799 * *$ & $0.799 * *$ & $0.710^{*}$ & $0.899 * * *$ & n.s. & n.s. & $0.836^{* *}$ \\
\hline CHS & n.s. & n.s. & $-0.849 * *$ & $-0.786^{* *}$ & $0.786^{* *}$ & $0.638^{*}$ & $0.822 * *$ & $0.709 *$ & n.s. & $0.838 * *$ \\
\hline $\mathrm{CHA}$ & n.s. & n.s. & $-0.838 * *$ & $-0.802 * *$ & $0.802^{* *}$ & $0.673^{*}$ & $0.754^{*}$ & $0.689^{*}$ & n.s. & $0.856^{* *}$ \\
\hline CFA & n.s. & n.s. & $-0.814^{* *}$ & $-0.706^{*}$ & $0.706^{*}$ & n.s. & $0.896 * * *$ & $0.701^{*}$ & n.s. & $0.750^{*}$ \\
\hline DH & n.s. & n.s. & $-0.877 * * *$ & $-0.642 *$ & $0.642 *$ & n.s. & n.s. & n.s. & n.s. & $0.719^{*}$ \\
\hline CHA:CFA & n.s. & n.s. & n.s. & n.s. & n.s. & n.s. & n.s. & n.s. & n.s. & $0.638^{*}$ \\
\hline $\begin{array}{l}\mathrm{Q}^{4 / 6} \mathrm{HS} \\
\end{array}$ & n.s. & n.s. & $0.791 * *$ & $0.833^{* *}$ & $-0.833 * *$ & $-0.720 *$ & $-0.687^{*}$ & $-0.699 *$ & n.s. & $-0.882 * *$ \\
\hline $\mathrm{Q}_{\mathrm{HA}}^{4 / 6}$ & n.s. & n.s. & 0.618 & $0.934 * * *$ & $-0.934 * * *$ & $-0.887 * * *$ & $-0.658 *$ & $-0.678^{*}$ & n.s. & $-0.963 * * *$ \\
\hline
\end{tabular}

$\mathrm{SOC}$ - soil organic carbon, $\mathrm{C}_{\mathrm{L}}$ - labile carbon, $\mathrm{C}_{\mathrm{HWE}}$ - hot water extracted carbon, $\mathrm{CaCO}_{3}-$ content of carbonates, CHS - humic substances carbon, CHA - humic acids carbon, CFA - fulvic acids carbon, $\mathrm{Q}^{4 / 6}$ - colour quotient 465 to $650 \mathrm{~nm}$, DSA $\mathrm{mi}_{\mathrm{i}}$ - dry sieved micro-aggregates, $\mathrm{DSA}_{\mathrm{ma}}$ - dry sieved macro-aggregates, $\mathrm{DSA}_{\mathrm{ma}} 0.5-3$ - dry sieved macro-aggregates from 0.5 to $3.0 \mathrm{~mm}$, WSA $\mathrm{Wi}^{-}$ water-stable micro-aggregates, $\mathrm{WSA}_{\mathrm{ma}}$ - water-stable macro-aggregates, $\mathrm{WSA}_{\mathrm{ma}} 0.5-3$ - water-stable macro-aggregates from 0.5 to $3.0 \mathrm{~mm}, \mathrm{MWDd}$ - mean weight diameters for dry sieved aggregates, MWDw - mean weight diameters for wet sieved aggregates, $\mathrm{Kv}$ - vulnerability coefficient, $\mathrm{Sw}-$ stability index of water-stable aggregates 
Many studies (Kassam et al. 2015, Blanco-Canqui and Ruis 2018; Zhang et al. 2018) reported negative tillage effects on soil structure. Tillage could result in the reduction of SOM stock, cation exchange capacity (CEC), nutrients content, and microbial and faunal activity, all of which contribute to soil aggregation (Plante and McGill 2002). However, carbonates were reported as a factor in decreasing the stability of micro-aggregates (Boix-Fayos et al. 2001), which is in opposition to our results obtained in the GS. Higher content of carbonates came together with a decrease in WSA $_{\mathrm{ma}}$, MWDd, MWDw and Sw. The effect of carbonates content on soil structure could be moderated by SOC (Chan and Heenan 1999) as an increase in $\mathrm{Sw}$ in limed soils suggests the formation of strong bonding, involving $\mathrm{Ca}^{2+}$ bridges between primary soil particles and SOM (Kobierski et al. 2018) and it promotes the formation of coarse aggregate fractions (Wang et al. 2013). Higher SOC content could be followed by an increase in dissolution and re-precipitation of carbonates in soil. At low SOC concentration, macro - aggregate stability is enhanced by carbonates (Boix-Fayos et al. 2001) which may explain the positive correlation between content of agronomically favourable size fraction of aggregates $(0.5-3.0 \mathrm{~mm})$ and carbonates content in the GS (Table 4). The results presented by Šimanský et al. (2014) showed that a more intense aggregation process in loamy soils (Bučany and Trakovice district) is related to high content of basic exchangeable cations, and high value of CEC and the stabile organic matter content in water-stable aggregates. Generally, the SOM has been linked to improved Sw (Nouwakpo et al. 2018) because the SOM is one of the most important binding agents (Bronick and Lal 2005; Rabbi et al. 2014). In the IC, a higher content of HA resulted in higher values of MWDd, and a higher stability of $\mathrm{HS}$ and $\mathrm{HA}\left(\mathrm{Q}^{4 / 6}{ }_{\mathrm{HS}}\right.$ and $\left.\mathrm{Q}^{4 / 6}{ }_{\mathrm{HA}}\right)$ resulted in higher values of MWDd. In the GS, a higher SOC resulted in increased content of $\mathrm{WSA}_{\mathrm{ma}}, \mathrm{MWDd}$, MWDw and Sw, but, by contrast, we observe a decrease in content of agronomically favourable size fractions of dry sieved aggregates and content of WSA $_{\text {mi }}$. Labile fractions of SOM can be a factor in transforming micro-aggregates into macro-aggregates (Six et al. 2004), which is confirmed by our results in the GS. Higher contents of $\mathrm{C}_{\mathrm{L}}$ and $\mathrm{C}_{\mathrm{HWE}}$ result in a decrease in $\mathrm{WSA}_{\mathrm{mi}}$ content, most probably due to the aggregation of smaller aggregates into bigger aggregates with labile carbon fraction. A positive link between size of aggregates and labile SOM has also been described by other researchers (Six et al. 2004, Polláková et al. 2018, Kobierski et al. 2018), indicating a greater role of $C_{L}$ in the formation of macro-aggregates than of micro-aggregates. In GS, statistically significant positive correlations were observed between $\mathrm{C}_{\mathrm{L}}$ and $\mathrm{WSA}_{\mathrm{ma}}$, WSA ${ }_{\mathrm{ma}} 0.5-3 \mathrm{~mm}, \mathrm{MWDd}$, $M W D w$ and $S w$. The aggregate binding effect of $C_{L}$ is rapid but transient (Kay 1998) while decomposing SOC fractions with lower decomposing rates have milder effects on aggregation, but its effects may last longer (Martens 2000). Higher contents of HS, HA and FA was followed by an increase of content $\mathrm{WSA}_{\mathrm{ma}}$ and $\mathrm{WSA}_{\mathrm{ma}} 0.5-3 \mathrm{~mm}, \mathrm{MWDd}, \mathrm{MWDw}$ and $\mathrm{Sw}$ in GS. A higher degree of humification of SOM also had a positive effect in increasing $\mathrm{WSA}_{\mathrm{ma}}(\mathrm{r}=0.642$, $\mathrm{P}<0.05)$ and $\mathrm{Sw}(\mathrm{r}=0.719, \mathrm{P}<0.05)$. Based on the negative correlation of $\mathrm{Q}^{4 / 6}{ }_{\mathrm{HS}}$ and $\mathrm{Q}^{4 / 6}{ }_{\mathrm{HA}}$ with $\mathrm{WSA}_{\mathrm{ma}}, \mathrm{WSA}_{\mathrm{ma}} 0.5-3 \mathrm{~mm}, \mathrm{MWDd}, \mathrm{MWDw}$ and Sw values, we can conclude that more condensed (humified) fractions of humus dominated in the formation of favourable soil structure. Optimal soil structure as reported by Kimura et al. (2017) and Polláková et al. (2018) is formed through more humified humus fractions.

\section{CONCLUSIONS}

Even though parameters of soil structure parameters differed according to the morphological parts of analysed slopes (S, SH, BS, TS, F) and between both types of soil management (IC vs. GS), not all of them changed significantly along the slope. Only in greening system did the favourable size fraction of water-stable macro-aggregates show a statistically significant quadratic polynomial trend along the slope. In the intensively cultivated slope the values of mean weight diameter of aggregates decreased in a statistically significant way down the slope, while in the greening system the mean weight diameter of aggregates increased, and this trend was expressed with the quadratic polynomial model. Between inorganic carbon $\left(\mathrm{CaCO}_{3}\right)$ and organic $\mathrm{C}$ forms and soil structure parameters significantly more relationships were found in the greening system. We can conclude that more labile SOM fractions and more humified fractions of humus together dominated the formation of favourable soil structure in the greening system. The results indicate that soil management practices can significantly affect the relationship between SOM quality and soil structure development. 


\section{ACKNOWLEDGMENTS}

This study was supported by the Scientific Grant Agency (VEGA) - project No. 1/0136/17.

\section{REFERENCES}

Barthés B., Roose E., 2002. Aggregate stability as an indicator of soil susceptibility to runoff and erosion; validation at several levels. Catena 2002(47): 133-149.

Bronick C.J., Lal R., 2005. The soil structure and land management: a review. Geoderma 124(1-2): 3-22.

Boix-Fayos C., Calvo-Cases A., Imeson A.C., Soriano-Soto M.D., 2001. Influence of soil properties on the aggregation of some Mediterranean soils and the use of aggregate size and stability as land degradation indicators. Catena 44: 47-67.

Blanco-Canqui H., Ruis S.J., 2018. No-tillage and soil physical environment. Geoderma 326: 164-200.

Chan K.Y., Heenan D.P., 1999. Lime-induced loss of soil organic carbon and effect on aggregate stability. Soil Science Society of America Journal 63(6): 1841-1844.

Cambardella C.A., Elliot E.T., 1992. Particulate Soil OrganicMatter across a Grassland Cultivation Sequence. Soil Science Society of America journal 56(3): 777-783.

Chun-Chih T., Zueng-Sang Ch., Chang-Fu H., 2004. Relationships between soil properties and slope position in a lowland rain forest of southern Taiwan. Geoderma 132(1-2): 131142.

Dominati E., Patterson M., Mackay A., 2010. A framework for classifying and quantifying the natural capital and ecosystem services of soils. Ecological Economy 69(9): 1858-1868.

Demo M., Kollár B., Hraško J., 1995. Obrábanie pôdy (Soil tillage). 1st ed. SUASlovak University of Agriculture, Nitra: 315 pp. (in Slovak).

Dziadowiec H., Gonet S.S., 1999. Przewodnik metodyczny do badań materii organicznej gleb (Methodological guidebook for the organic matter researches). Prace Komisji Naukowych Polskiego Towarzystwa Naukowego 120: 31-34 (in Polish).

Efthimiou N., 2018. The importance of soil data availability on erosion modeling. Catena 165: 551-566.

Gajewski P., Kaczmarek Z., Owczarzak W., Glina B., MocekPłóciniak A., Gaweł E., Grzelak M., Świerk D., 2016. The influence of the em-preparation on the properties of structure in arable mineral soils. Fresenius Environmental Bulletin 25(10): 4184-4191.

Gregorich E.G., Greer K.J., Anderson D.W., Liang B.C., 1998. Carbon distribution and losses: erosion and depositional effects. Soil and Tillage Research 47(3-4): 291-302.

Fiedler H.J., Reissing H., 1964. Lehrbuch den Bodenkunde. VEB Fleicher, Jena: 544 pp.

Hrivňáková K., Makovníková J., Barančíková G., Bezák P., Bezáková Z., Dodok R., Grečo V., Chlpík J., Kobza J., Lištjak M., Mališ J., Píš V., Schlosserová J., Slávik O., Styk J., Širáň M., 2011. Uniform methods of soil analyses. VÚPOP, Bratislava, 136 pp.

Kassam A., Friedrich T., Derpsch R., Kienzle J., 2015. Overview of the worldwide spread of conservation agriculture. Field Actions Science Reports 8: 1-11.

Kay B.D., 1998. Soil structure and organic carbon: a review. [In:] Soil Processes and the Carbon Cycle (Lai R., Kimble
J.M., Follett R.F., Stewart B.A., Editors). CRC Press LLC., Boca Raton: 169-197.

Kimura A., Baptista M.B., Scotti M.R., 2017. Soil humic acid and aggregation as restoration indicators of a seasonally flooded riparian forest under buffer zone system. Ecological Engineering 98: 146-156.

Kobierski M., Kondratowicz-Maciejewska K., Banach-Szott M. Wojewódzki, Petas Castejón J.M., 2018. Humic substances and aggregate stability in rhizospheric and non-rhizospheric soil. Journal of Soils and Sediments 18(8): 2777-2789.

Körschner M., Schulz E., Behm R., 1990. Heisswasserlőslicher $\mathrm{C}$ und $\mathrm{N}$ im Boden als Kriterium für das N-Nachliferungsvermőgen. Mikrobiologie 145: 305-311.

Laatsh W., 1954. Dynamik der Mitteleuropäischen Mineralböden. Steinkopf, Dresden: 277 pp.

Liang Y., Li D.C., Lu X.X., Yang X., Pan X.Z., Mu H., Shi D.M., Zhang B., 2010. Soil erosion changes over the past five decades in the red soil region of southern China. Journal of Mountain Science 7(1): 92-99.

Loginow W., Wisniewski W., Gonet S.S., Ciescinska B., 1987. Fractionation of organic carbon based on susceptibility to oxidation. Polish Journal of Soil Science 20: 47-52.

Mückenhausen E., 1975. Die Bodenkunden und ihre geologischen, geomorphologishen, mineralogischen und petrologishen Grundlagen. DLG Verlag, Frankfurt am Main: 579 pp.

Nabiollahi K., Golmohamadi F., Taghizadeh-Mehrjardi R., Kerry R., Davari M., 2018. Assessing the effects of slope gradient and land use change on soil quality degradation through digital mapping of soil quality indices and soil loss rate. Geoderma 318: 16-28.

Martens D.A., 2000. Plant residue biochemistry regulates soil carbon cycling and carbon sequestration. Soil Biology and Biochemistry 32(3): 361-369.

Nouwakpo S.K., Song J., Gonzalez J.M., 2018. Soil structural stability assesment with the fluidized bed, aggregate stability, and rainfall simulation on long-term tillage and crop rotation systems. Soil and Tillage Research 178: 65-71.

Paz-Kagan T., Ohana-Levi N., Herrmann I., Zaady E., Henkin Z., Karnieli A., 2016. Grazing intensity effects on soil quality: A spatial analysis of a Mediterranean grassland. Catena 146: $100-110$.

Polláková N., Šimanský V., Kravka M., 2018. The influence of soil organic matter fractions on aggregates stabilization in agricultural and forest soils of selected Slovak and Czech hilly lands. Journal of Soil and Sediments Soils Sediments 18: 2790-2800.

Plante A.F., McGill W.B., 2002. Soil aggregate dynamics and the retention of organic matter in laboratory-incubated soil with differing simulated tillage frequencies. Soil and Tillage Research 66(1): 79-92.

Rabbi S.M.F., Wilson B.R., Lockwood P.V., Daniel H., Young I.M., 2014. Soil organic carbon mineralization rates in aggregates under contrasting land uses. Geoderma 216: $10-18$.

Rząsa S., Owczarzak W., 2004. Struktura gleb mineralnych (Structure of mineral soils). Wyd. Akademii Rolniczej im. Augusta Cieszkoweskiego, Poznań: 393 pp. (in Polish with English summary).

Shukla M.K., 2014. Soil Physics: An Introduction. CRC Press, Taylor and Francis Group, Boca Raton, London, New York, $458 \mathrm{pp}$. 
Six J., Bossuyt D.E., Gryze S., Denef K., 2004. A history of research on the link between (micro) aggregates, soil biota, and soil organic matter dynamics. Soil and Tillage Research 79(1): 7-31.

Societas Pedologica Slovaca, 2014. Morfogenetický klasifikačný system pôd Slovenska. (Morphogenetic Soil Classification System of Slovakia). Výskumný ústav pôdoznalectva a ochrany pôdy, Bratislava: 96 pp. (in Slovak).

Soil Survey Division Staff, 1993. Soil Survey Manual. Soil Conservation Service. U.S. Department of Agriculture Handbook 18

Steinhoff-Knopp B., Burkhard B., 2018. Soil erosion by water in Northern Germany: long-term monitoring results from Lower Saxony. Catena 165: 299-309.

Šimanský V., Kolenčík M., Puškel'ová L'. 2014. Effects of carbonates and bivalent cations and their relationships with soil organic matter from the view point of aggregate formation. Agriculture (Pol'nohospodárstvo) 60(3): 77-86.

Šimanský V., Polláková N., Chlpík J., Kolenčík M., 2018. Pôdoznalectvo (Soil Science). SPU, Nitra: 399 pp.

Tarábek K., 1980. Klimatogeografické typy (Climatogeographical Types), 1:1 000 000. Atlas of Slovak republic, SAV, SÚGK, Bratislava: 64.

Tisdall J.M., Oades J.M., 1982. Organic matter and water-stable aggregates in soils. Journal of Soil Science 33(2): 141-163.
Tisdall J.M., 1996. Formation of soil aggregates and accumulation of soil organic matter. [In:] Structure and Organic Matter Storage in Agricultural Soils (Carter M.R., Stewart B.A., Editors). Lewis Publishers, Boca Raton: 57-96.

Vadjunina A.F., Korchagina Z.A., 1986. The methods of the research of the physical properties of soils. Agropromizdat, Moscow: $415 \mathrm{pp}$.

Valla M., Kozák J., Ondráček V., 2000. Vulnerability of aggregates separated from selected anthrosols developed on reclaimed dumpsites. Rostlinná Výroba 46(12): 563-568.

Wang S., Zheng Z., Li T., Li Y., 2013. Effects of age of tea plantations on distribution of exchangeable base cations in soil aggregates. Acta Pedologica Sinica 50(5): 1014-1021.

Zaujec A., Šimanský V., 2006. Vplyv biostimulátorov rozkladu rastlinných zvyškov na pôdnu štruktúru a organickú hmotu pôdy (Effect of biostimulators of the plant residues degradation on the soil structure and soil organic matter). SPU, Nitra: 112 pp.

Zhang G.H., Liu G.B., Tang K.M., Zhang X.C., 2008. Flow detachment of soils under different land use in the Loess Plateau of China. Transactions of ASABE 51(3): 883-890.

Zhang X., Xin X., Zhu A., Yang W., Zhang J., Ding S., Mu L., Shao L., 2018. Linking macroaggregation to soil microbial community and organic carbon accumulation under different tillage and residue managements. Soil and Tillage Research 178: 99-107.

Received: February 4, 2019

Accepted: July 29, 2019

Associated editor: J. Rejman

\section{Wpływ pozycji na stoku i sposobu użytkowania na wybrane właściwości w przypowierzchniowej warstwie gleby}

Streszczenie: Celem badań była ocena wybranych parametrów (w tym jakości struktury agregatowej) w przypowierzchniowej warstwie gleby w odniesieniu do nachylenia stoku (pozycji na zboczu) i sposobu użytkowania gleby w Trakovicach (kraj trnawski, Słowacja). Obszar badań obejmował dwa sąsiadujące ze sobą pola położone na stoku o orientacji NW-SE, nachylonym pod kątem około $8^{\circ}$. Pole $\mathrm{nr} 1$ było intensywnie użytkowane jako grunt orny, podczas gdy na polu nr 2 znajdował się tzw. zielony ugór (przez okres 6 lat poprzedzających pobór próbek). Próbki gleby pobierano z poziomów próchnicznych w pięciu wyznaczonych strefach geomorfologicznych (szczyt, górna część stoku, środkowa część stoku, dolna część stoku i podnóże stoku) na każdym zboczu. Wyniki jednoczynnikowej analizy wariancji (ANOVA) wykazały istotny statystycznie wpływ sposobu użytkowania stoku na $\mathrm{pH}$ gleby, zawartość $\mathrm{CaCO}_{3}$, zawartość węgla w substancjach humusowych i węgla kwasów huminowych (wyrażonych jako udział wyżej wymienionych w ogóle węgla glebowej materii organicznej) oraz badane parametry struktury gleb. Udział procentowy WSA $_{\text {ma }}$ 0,5-3 mm (water stable macro-aggregates) na ugorowanej części stoku wykazywał istotny statystycznie trend (wielomian kwadratowy) wzdłuż nachylenia zbocza. Wartości średniej ważonej średnicy agregatów przesiewanych na sucho (MWDd) na intensywnie użytkowanym stoku zmniejszyły się istotnie wzdłuż gradientu nachylenia, podczas gdy na stoku ugorowanym zaobserwowano przeciwną tendencję. Jednocześnie stwierdzono istotną statystycznie korelację pomiędzy wartościami tego parametru a zawartością węglanów $(\mathrm{r}=-0,775, \mathrm{p}<0,01)$, zawartością kwasów huminowych $(\mathrm{r}=0,654, \mathrm{p}<0,05)$, indeksem $\mathrm{Q}^{4 / 6}$ określonym dla substancji humusowych $\left(Q^{4 / 6}{ }_{H S} ; r=-0,706, p<0,05\right)$ oraz dla kwasówhuminowe $\left(Q^{4 / 6}{ }_{H A} ; r=-0,723, p<0,05\right)$. Na stoku ugorowanym wraz z wyższą zawartością węglanów obniżał się udział makro agregatów stabilnych w wodzie, oraz średniaważona średnica agregatów przesiewanych na sucho i na mokro oraz wartości indeksu stabilności agregatów (Sw). Jednocześnie wyższe zawartości materii organicznej (zarówno form stabilnych i labilnych) wpływały na poprawienie struktury powierzchniowych poziomów glebowych.

Stowa kluczowe (for Polish authors only): struktura gleby, glebowa materia organiczna, intensywne użytkowanie, ugór, stok 